28 Parker C, Philp I. Screening for cognitive impairment among older people in black and minority ethnic groups. Age Ageing 2004; 33: 447-52.

29 Johnson MR, Cross M, Cardew SA. Inner-city residents, ethnic minorities and primary health care. Postgrad Med J 1983; 59: 664-7.

30 Richards M. Surveying African Caribbean elders in the community: implications for research on health and health service use. Int J Ger Psychiatry 1996; 11: 41-5.

31 Livingston G, Leavey G, Kitchen G, Manela M, Sembhi S, Katona C. Mental health of migrant elders - the Islington study. Br J Psychiatry 2001; 179: $361-6$.
32 McCracken CF, Boneham MA, Copeland JR, Williams KE, Wilson K, Scott A et al. Prevalence of dementia and depression among elderly people in black and ethnic minorities. Br J Psychiatry 1997; 171: 269-73.

33 Richards M, Brayne C, Dening T, Abas M, Carter J, Price M, et al. Cognitive function in UK community-dwelling African Caribbean and white elders: a pilot study. Int J Geriatr Psychiatry 2000; 15: 621-30.

34 Fish M, Bayer AJ, Gallacher JE, Bell T, Pickering J, Pedro $\mathrm{S}$, et al. Prevalence and pattern of cognitive impairment in a community cohort of men in South Wales: methodology and findings from the Caerphilly Prospective Study. Neuroepidemiology 2008; 30: 25-33.

35 Knapp M. Dementia UK - The Full Report. London School of Economics, King's College London, 2007.

\title{
extra Exposure to chemical warfare during the First World War: shell shock poetry of Wilfred Owen
}

\section{Menachem Ben-Ezra}

One of the most striking personal accounts of psychological reactions to chemical gas attack during the First World War can be seen in the poem Dulce et decorum est pro patria mori:

( . . . ) Gas! GAS! Quick, boys! - An ecstasy of fumbling

Fitting the clumsy helmets just in time,

But someone still was yelling out and stumbling

And flound'ring like a man in fire or lime. -

Dim through the misty panes and thick green light,

As under a green sea, I saw him drowning.

In all my dreams before my helpless sight

He plunges at me, guttering, choking, drowning.

If in some smothering dreams, you too could pace

Behind the wagon that we flung him in,

And watch the white eyes writhing in his face,

His hanging face, like a devil's sick of sin,

If you could hear, at every jolt, the blood

come gargling from the froth-corrupted lungs

Bitter as the cud of vile, incurable sores on innocent tongues ( . . . )

The symptoms of exposure to poison gases used during the First World War (chlorine or phosgene in most cases) are described in the bodily reaction to these chemicals that affect the lungs, skin and mucous membranes. When the lungs are affected the feeling is of one gasping for air and drowning.

Owen's account meets several symptom clusters of post-traumatic stress disorder in the DSM-IV-TR. Exposure to poison gas attack is considered a traumatic event meeting criterion A. Re-experiencing is presented by an intrusive recollection of the attack via disturbing dreams that haunted the person in the poem. Increased arousal is described in the tone and description of the reactions to the gas attack along with sleep disturbances.

It should be noted that Owen had experienced two more major traumatic events during the First World War: being thrown in the air by the blast of a trenched mortar and landing on the remains of fellow officer, and being trapped for days in an old German dug-out Later on, he was diagnosed as suffering from shell shock and was sent to Craiglockhart War Hospital in Edinburgh. During his time at the hospital, he was influenced by the poet Siegfried Sassoon who had encouraged Owen to explore in his poetry the symptoms of shell shock such as flashbacks, recurrent and repetitive nightmares, and intrusive memories of battle. After returning to his regiment, Owen was killed in action on 4 November 1918 during the crossing of the Sambre-Oise Canal.

Menachem Ben-Ezra, School of Social Work, Ariel University Center of Samaria, Ariel, Israel. 